Journal of Epidemiology and Community Health, 1985, 39, 353-356

\title{
Trauma to the nervous system and its sequelae in a one-year birth cohort followed up to the age of 14 years
}

\author{
PAULA RANTAKALLIO ${ }^{1}$ AND LENNART VON WENDT ${ }^{2}$ \\ From the Departments of Public Health Science, ${ }^{1}$ and Paediatrics, ${ }^{2}$ University of Oulu, Oulu, Finland
}

SUMMARY The one-year birth cohort of 12058 children, $96 \%$ of all children born in the two northernmost provinces of Finland, Oulu and Lapland, in 1966 was studied prospectively up to the age of 14 years. During this period 14 children, 1.2 per thousand, were lost from the follow-up. Data on development, mortality, and morbidity were collected prospectively by means of questionnaires and from various registers, the most important of which was the National Hospital Discharge Register. A total of 299 cases of trauma to the nervous system (skull fracture, cerebral contusion, concussion, fracture of the vertebral column with spinal lesion, injury to the cranial or peripheral nerves) occurred in 286 children, 116 girls and 170 boys, which yields a cumulative incidence of nervous system trauma of 24.1 per thousand. The trauma was fatal in 11 boys and 7 girls, 63 per thousand of all children with neurotrauma, and 136 per thousand of all cases of death occurring in the age group 29 days to 14 years. Spinal injury occurred in 12 children, cerebral contusion in 28 , skull fracture in 19 , and concussion in 216 . Such trauma resulted in chronic disease, cerebral palsy, mental retardation, and epilepsy in 16 children, $5.6 \%$ of all children with neurotrauma and $3.2 \%$ of the 495 children in the cohort with cerebral palsy, epilepsy or mental retardation only.

Accidents are at present the major cause of postneonatal mortality and morbidity among children in the developed countries. ${ }^{1-4}$ According to Marcusson \& Oehmisch, ${ }^{1}$ accidents account for well over $50 \%$ of deaths among children aged 1 to 14 years in these countries. The British 1958 cohort, National Child Developmental Study, showed that $0.1 \%$ of the children died accidentally before the age of $7 .^{5}$ There are several other studies dealing with the incidence of childhood accidents, predisposing factors, and their prevention, but these are usually so different in study design that comparability of the results is seriously hampered. ${ }^{6-10}$ Trauma to the nervous system, especially head trauma, carries a risk of either death or chronic disablement, and divergent outcome patterns for such accidents have been reported in hospital-based series. ${ }^{11,12}$ On the other hand, relatively little has been said about the total impact of nervous system trauma on chronic disablement in childhood in the framework of a defined population. ${ }^{13}$

The 1966 one-year birth cohort from northern Finland, comprising 12058 live-born infants, has now been studied up to the age of 14 years, and the incidences and aetiological risk factors for chronic disease have been calculated. ${ }^{14,15}$ On the basis of these data it is possible to evaluate the long-term effect of nervous system trauma in childhood.

\section{Series and methods}

The series consists of 12058 liveborn children from the provinces of Oulu and Lapland, covering $96 \%$ of all children born in this region in $1966 .{ }^{16}$ Only 14 children, 1.2 per thousand, were lost during the prospective follow-up period of 14 years.

Collection of the series and data on the families and children was started during pregnancy, and later data were compiled basically in the following way: ${ }^{17}$

- Questionnaires concerning the pregnancy, the perinatal period, and later morbidity and school achievements were filled in by health care staff, parents, and the children themselves.

- Diagnosis given on admission to hospitals in the region and throughout Finland were recorded prospectively and stored. Registers of children receiving various types of social insurance support were also used to identify children with chronic disability. Relevant information 
from other registers on children with chronic diseases was also entered into the records. ${ }^{17}$ During the final process of identifying children with neurological diseases the registers of hospitals in the region were surveyed for information on children in the cohort. ${ }^{15,18}$

The criterion for mental retardation used in this study was an IQ of $85,{ }^{14}$ while cerebral palsy was defined in accordance with the principles of the Little Club of London $1959^{15,19}$ and epilepsy in accordance with the International Classification. ${ }^{18,20}$ The 1975 International Classification of $\mathrm{WHO}^{21}$ was used for the identification and definition of nervous system trauma. The cases accepted included trauma to the skull, cranial fracture, cerebral contusion and concussion, vertebral column trauma if there was also injury to the spinal cord, and trauma to the peripheral nerves.

\section{Results}

The total cumulative incidence of nervous system trauma up to the age of 14 years was 24.1 per thousand (table 1 ). The trauma was fatal in 18 children, 11 boys and 7 girls, 63 per thousand of all children with this type of trauma (table 1) and 136 per thousand of all deaths occurring in the age group 29 days to 14 years. The total number of children dying in this period was 132 , of whom $44(33 \%)$ died of accidents. Eleven children died of drowning and one child suffered mental retardation and cerebral palsy following rescue after drowning but is not included in the study. Thus $40 \%$ of postneonatal accidental deaths were caused by trauma to the nervous system. The mean age of death following neurotrauma was 6.5 years, ranging from 9.5 months to 11.5 years. Cerebral contusion with or without simultaneous skull fracture was reported in $\mathbf{2 8}$ children, with a cumulative incidence of 2.4 per thousand, or $9.8 \%$ of all children with nervous system trauma. The most frequently occurring injury was concussion with or without skull fracture, encountered in 216 children, yielding a cumulative incidence of 18.1 per thousand and representing $75.5 \%$ of all nervous system trauma cases (table 1). The majority, 272 out of 299 , or $91 \%$ of the CNS trauma episodes, occurred after the age of 3 years (table 2). A total of 16 children, $5.6 \%$ of all children with trauma to the nervous system, sustained a residual chronic handicap as a consequence, and four children developed multiple handicap. The distribution of the chronic handicaps is presented in table 3.

In the total cohort there were 495 children witho cerebral palsy, epilepsy or mental retardation, of which $2.5 \%$ suffered such neurotrauma which did not cause? their handicaps. On the other hand, $4.9 \%$ of the children 0 with epilepsy, $7.3 \%$ of the children with cerebral palsy, $\omega$ and $1.5 \%$ of the children with an IQ lower than $86 \mathrm{n}$ 윽 developed their handicap as a consequence of $\rightarrow$ neurotrauma.

Table 1 Nervous system trauma up to 14 years of age in the 1966 Northern Finland cohort

\begin{tabular}{|c|c|c|c|c|c|c|}
\hline Type of trauma & Girls & Boys & Total & Deaths & $\begin{array}{l}\text { Cumulative } \\
\text { incidence per } \\
\text { /000 alive at } \\
\text { lyear } \\
(N=11,870)\end{array}$ & $\begin{array}{l}\% \text { of all } C N S \\
\text { trauma } \\
(N=286)\end{array}$ \\
\hline Concussion & 85 & 128 & 213 & & 17.9 & 74.5 \\
\hline Concussion and cranial fracture & 2 & 1 & 3 & & 0.25 & 1.1 \\
\hline Cerebral contusion & 10 & 9 & 19 & 1 & 1.60 & 6.6 \\
\hline Cranial fracture & 9 & 10 & 19 & 8 & 1.60 & 6.6 \\
\hline Cerebral contusion and cranial fracture & 2 & 7 & 9 & & 0.76 & 3.1 \\
\hline $\begin{array}{l}\text { Spinal fracture and spinal } \\
\text { cord lesion }\end{array}$ & 3 & 9 & 12 & 9 & 1.01 & 4.2 \\
\hline Intracranial haemorrhage & 2 & 5 & 7 & & 0.59 & 2.5 \\
\hline Miscellaneous & 3 & 1 & 4 & & 0.34 & 1.4 \\
\hline Total & 116 & 170 & 286 & 18 & 24.09 & 100.0 \\
\hline
\end{tabular}

Table 2 Nervous system trauma episodes by age group

\begin{tabular}{|c|c|c|c|c|c|c|c|c|c|c|c|c|}
\hline \multirow{3}{*}{ Type of trauma } & \multicolumn{12}{|c|}{ Age (years) } \\
\hline & \multicolumn{2}{|l|}{$<1$} & \multicolumn{2}{|c|}{$1<3$} & \multicolumn{2}{|c|}{$3<7$} & \multicolumn{2}{|c|}{$7<10$} & \multicolumn{2}{|c|}{$10<14$} & \multicolumn{2}{|c|}{ Total } \\
\hline & $N$ & $\%$ & $N$ & $\%$ & $N$ & $\%$ & $N$ & $\%$ & $N$ & $\%$ & $N$ & $\%$ \\
\hline Concussion & 8 & 3.7 & 11 & 5.1 & 59 & 27.3 & 63 & 29.2 & 75 & 34.7 & 216 & 72.2 \\
\hline Cerebral contusion & 0 & 0.0 & 1 & 3.5 & 11 & 37.9 & 7 & 24.1 & 10 & 34.5 & 29 & 9.7 \\
\hline $\begin{array}{l}\text { Intracranial } \\
\text { haemorrhage }\end{array}$ & 2 & 28.6 & 1 & 14.3 & 1 & 14.3 & 1 & 14.3 & 2 & 28.6 & 7 & 2.3 \\
\hline Skull fracture & 2 & 6.5 & 1 & 3.2 & 12 & 38.7 & 9 & 29.0 & 7 & 22.6 & 31 & 10.4 \\
\hline Spinal lesion & 1 & 7.6 & 0 & 0.0 & 6 & 46.2 & 3 & 23.1 & 3 & 23.1 & 13 & 4.4 \\
\hline Other & 0 & 0.0 & 0 & 0.0 & 1 & 33.3 & 0 & 0.0 & 2 & 66.7 & 3 & 1.0 \\
\hline Total & 13 & 4.3 & 14 & 4.7 & 90 & 30.1 & 83 & 27.8 & 99 & 33.1 & 299 & 100.0 \\
\hline
\end{tabular}


Table 3 Distribution of chronic neurological handicaps among 16 children who developed one or several sequelae after CNS trauma

\begin{tabular}{lllllc}
\hline & \multicolumn{2}{l}{ Chronic disorder } & & & \\
\cline { 2 - 6 } Type of trauma & Epilepsy & $\begin{array}{l}\text { Cerebral } \\
\text { palsy }\end{array}$ & $\begin{array}{l}\text { Mental } \\
\text { retardation }\end{array}$ & $\begin{array}{l}\text { Chronic disorder } \\
\% \text { of all injured }\end{array}$ & Per injured \\
\hline $\begin{array}{l}\text { Concussion with or without } \\
\text { cranial fracture }\end{array}$ & 3 & - & - & 1.4 & $3 / 216$ \\
$\begin{array}{l}\text { Cerebral contusion with or without } \\
\text { cranial fracture }\end{array}$ & 5 & 4 & 4 & 46.4 & $13 / 28$ \\
$\begin{array}{l}\text { Intracranial haemorrhage } \\
\begin{array}{l}\text { Other } \\
\text { Total }\end{array}\end{array}$ & 2 & 1 & 1 & 57.1 & $4 / 7$ \\
\hline
\end{tabular}

Of the 266 surviving children with neurotrauma, 213 $(86.8 \%)$ were able to attend an ordinary school in a class appropriate to their age at the age of 14 , compared to $94.2 \%$ of all children without neurotrauma, the difference being significant $\left(p=0.0000, \chi^{2}\right.$ test) (table 4). Of 268 children with nonfatal neurotrauma, one died of bacterial meningitis not associated with neurotrauma and another belonged to the group of untraceable children, leaving 266 children for the evaluation of school performance.

\section{Discussion}

This study can be assumed to be an almost complete cover of severe neurotrauma, since it is based on records of all cases of trauma leading to hospitalisation in this birth cohort of 12058 children. As expected, cerebral concussion is the predominant type of injury, but this dominance could perhaps be envisaged as being still more marked, since all cases occurring at home may not have been reported. The main results of this study are that it is relatively rare for severe neurotrauma either to prove fatal or to leave any persistent sequelae, as only 16 children suffered chronic disease attributable to neurotrauma. As there were $\mathbf{4 9 5}$ children in the total series with mental retardation, cerebral palsy or epilepsy, and only 16 of them developed these conditions following neurotrauma, it seems that this type of accident is still of minor importance as an aetiological factor in these disorders. School achievement is probably a more sensitive indicator of minor developmental handicap, and the fact that these children as a group differed significantly from the others in the cohort seems to show that neurotrauma may give rise to minor dysfunction. Naturally it might be argued that children with learning problems are more prone to accidents than average children, and this factor may contribute to the over-representation of those children with subnormal school performance. ${ }^{22}$ Unfortunately, other available population-based studies of accidents in childhood do not present the results in similar target-organ specific subgroups. Therefore meaningful comparisons of the eventual prognoses between other studies cannot be made.

Since 18 children, $0.15 \%$, died after CNS trauma up to the age of 14 years, and $0.1 \%$ of the children in the British 1958 cohort died accidentally before the age of 7 years, when all types of accidents were included, it also seems evident that the total number of fatal accidents was higher in the present study. ${ }^{5}$

The preponderance of boys in both the mortality figures and accident rates is in good agreement with most other studies on childhood accidents. Rivara et al, ${ }^{23}$ for instance, report an over-representation of boys among

Table 4 Distribution of children with trauma to the nervous system by type of school at age 14.

\begin{tabular}{|c|c|c|c|c|c|c|c|c|c|c|}
\hline \multirow{3}{*}{ Type of trauma } & \multicolumn{10}{|c|}{ School } \\
\hline & \multicolumn{2}{|c|}{$\begin{array}{l}\text { Normal school } \\
\text { class appropriate } \\
\text { for age }\end{array}$} & \multicolumn{2}{|c|}{$\begin{array}{l}\text { Normal school } \\
\text { class lower } \\
\text { than normal }\end{array}$} & \multicolumn{2}{|c|}{$\begin{array}{l}\text { School for mentally } \\
\text { subnormal or } \\
\text { handicapped } \\
\text { children }\end{array}$} & \multicolumn{2}{|c|}{$\begin{array}{l}\text { Not at } \\
\text { school }\end{array}$} & \multirow[t]{2}{*}{$\begin{array}{l}\text { Total number } \\
\text { of children }\end{array}$} & \multirow[t]{2}{*}{$\begin{array}{l}\text { Percentage of } \\
\text { children not receiving } \\
\text { normal schooling }\end{array}$} \\
\hline & $N$ & $\%$ & $N$ & $\%$ & $N$ & $\%$ & $N$ & $\%$ & & \\
\hline \multicolumn{11}{|l|}{$\begin{array}{l}\text { Concussion with or } \\
\text { without skull } \\
\text { fracture }\end{array}$} \\
\hline $\begin{array}{l}\text { fracture } \\
\text { Cerebral contusion } \\
\text { with or without }\end{array}$ & 191 & 89.3 & 13 & 6.0 & 6 & 2.8 & 4 & 1.9 & 214 & 10.7 \\
\hline $\begin{array}{c}\text { fracture } \\
\text { Intracranial }\end{array}$ & 18 & 69.2 & 7 & 26.9 & 1 & 3.9 & 0 & 0.0 & 26 & 30.8 \\
\hline haemorrhage & 6 & 85.7 & 0 & 0.0 & 1 & 14.3 & 0 & 0.0 & 7 & 14.3 \\
\hline $\begin{array}{l}\text { Other } \\
\text { All children with } \\
\text { nervous system }\end{array}$ & 16 & 84.2 & 0 & 0.0 & 3 & 15.8 & 0 & 0.0 & 19 & 15.8 \\
\hline trauma & 231 & 86.8 & 20 & 7.6 & 11 & 4.1 & 4 & 1.5 & 266 & 13.2 \\
\hline
\end{tabular}


childhood accidents, which increases with age and reaches a rate of $90 \%$ more injuries in teenagers. The age distribution for accidents also shows the characteristic curve for developed countries, a rapid rise starting at preschool age. ${ }^{7}$

A reduction in accidents has taken place in Finland and the other Nordic countries during the last decade, ${ }^{4}$ but the present results seem to suggest that such a reduction in neurotrauma would in the first place lead to a reduction in the postneonatal death rate but would not substantially reduce the number of children with chronic neurological disease.

This study was supported by grants from the Academy of Finland.

\section{References}

${ }^{1}$ Marcusson H, Oehmisch W. Accident mortality in childhood in selected countries of different continents, 1950-1971. World Health Statistics Report 1977; 30: 57-116.

${ }^{2}$ Rivara FP. Childhood injuries. III: Epidemiology of non-motor vehicle head trauma. Dev Med Child Neurol 1984; 26: 81-7.

${ }^{3} \mathrm{Janec} M$. The rate of accidental injuries in childhood morbidity and lethality. Acta Chir Hung 1979; 20: 301-5.

${ }^{4}$ Jakobsson G, Köhler L. Barns hälsotillstånd i Norden. Stockholm: The Nordic School of Public Health, Rapport NHV 1984: 3 .

${ }^{5}$ Davie R, Butler N, Goldstein H. From birth to seven. A report of the national child development study. London: Longman, 1972.

${ }^{6}$ Gustafsson LH. Childhood accidents. Three epidemiological studies on the etiology. Scand J Soc Med 1977; 5: 5-13.

${ }^{7}$ Gratz RR. Accidental injury in childhood: a literature review on paediatric trauma. JTrauma 1979; 19: 551-5.

${ }^{8}$ Zink C, Karsten J, v. Törne J, Zink A, Korporal J. Epidemiologische und sozialspychologische Aspekte von Unfällen in Kindesalter. Monatsschr Kinderheilkd 1980; 128: 496-501.
${ }^{9}$ Wadsworth J, Burnell I, Taylor B, Butler N. Family type and accidents in preschool children. J Epidemiol Community Health 1983; 37: 100-4.

${ }^{10}$ Gallagher SS, Finison K, Guyer B, Goodenough S. The incidence of injuries among 87,000 Massachusetts children and adolescents: results of the 1980-81 statewide childhood injury prevention program surveillance system. Am J Public Health 1984; 74: 1340-7.

${ }^{11}$ Kretschmer $\mathrm{H}$. Prognosis of severe head injuries in childhood and adolescence. Neuropediatrics 1983; 14: 176-81.

${ }^{12}$ Heiskanen $\mathrm{O}$, Kaste M. Late prognosis of severe brain injury in children. Dev Med Child Neurol 1974; 16: 11-4.

${ }^{13}$ Rosenbloom L. Chronic central nervous system disease in childhood. In: Hull D, ed. Recent advances in paediatrics. Edinburgh: Churchill Livingstone, 1981: 213-36.

${ }^{14}$ Rantakallio $P$, von Wendt $L$. Mental retardation and subnormality in a birth cohort of 12,000 children in Northern Finland, a prospective study. Am J Ment Defic, in press.

${ }^{15}$ von Wendt L, Rantakallio P, Saukkonen A-L, Tuisku M, Mäkinen $H$. Cerebral palsy and additional handicaps in a one-year birth cohort from Northern Finland - a prospective follow-up study to the age of 14 years. Ann ClinRes, in press.

${ }^{16}$ Rantakallio P. Groups at risk in low birth weight infants and perinatal mortality. Acta Paediatr Scand 1969; suppl. 193: $1-71$.

${ }^{17}$ Rantakallio P. A 14-year follow-up of children with normal and abnormal birth weight for their gestational age. Acta Paediatr Scand 1985; 74: 62-9.

${ }^{18}$ von Wendt L, Rantakallio P, Saukkonen A-L, Mäkinen H. Epilepsy and associated handicaps in a one-year birth cohort in Northern Finland. Eur J Pediatr, in press.

${ }^{19}$ Pharoah POD. Epidemiology of cerebral palsy: a review. $J \boldsymbol{R}$ Soc Med 1981;74: 516-20.

${ }^{20} \mathrm{Gastaut} H$. Clinical and electroencephalographical classification of epileptic seizures. Epilepsia 1970; 11: 102-13.

${ }^{21}$ International Classification of Diseases. 1975 revision, vol 1.

Geneva: World Health Organization, 1977.
${ }^{22}$ Davidson L, Hughes S. Accidents in children: is hyperactive behaviour a risk factor. Am J Epidemiol 1984; 120 : 481.

${ }^{23}$ Rivara FP, Bergman AB, LoGerfo JP, Weiss NS. Epidemiology of childhood injuries. Am J Dis Child 1982; 136: 502-6. 